\title{
Aquacultural importance of the integumental pore pattern in postlarval whiteleg shrimp Litopenaeus vannamei (Decapoda: Penaeidae)
}

\author{
Jorge Alberto Cabrera-Jiménez \\ Instituto de Biología UNAM, Apartado Postal 70-153, 04510 México D. F.; jcabrera@ibiologia.unam.mx
}

Received 29-IX-2002. Corrected 08-V-2003. Accepted 20-X-2005.

\begin{abstract}
The analysis of integumental pore pattern has identified two intraspecific groups of postlarval shrimp Litopenaeus vannamei (Boone, 1931), a species of which three to five natural populations or groups are expected to be found from Mexico to Peru. Natural distribution and man-made redistributions have not been typified on a population basis in any penaeid, but it is important to do so in this commercially significant group. Important factors to be defined on a geographic population or group basis include differences in domesticity (eg resistance to pathological agents); food conversion indexes and food preferences; growth indices; tolerance to stress of various origins and other attributes useful in aquaculture. This consideration is valid not only for L. vannamei but also for any other shrimp species that has been the object of artificial redistribution. Rev. Biol. Trop. 54 (3): 707-709. Epub 2006 Sept. 29.
\end{abstract}

Key words: postlarval shrimp, aquaculture, penaeid shrimp populations, integumental pore pattern, Litopenaeus vannamei, opinion article.

Based on the integumental pore pattern, Alvarez-Silva and Ramirez-Ruiz (1999) characterized two intraspecific groups of the postlarval shrimp Litopenaeus vannamei (Boone, 1931). They follow the method used in taxonomic studies of calanoid copepods by Mauchline (1987) and distinguish organisms from Panama and Mexico whose portlarvae have three and four dorsal spines, but do not mention the aquacultural importance of their finding. The purpose of this paper is to stress that importance.

This is an urgent subject, full of questions and opportunities, because as stated by Lester (1979) different gene pools should be treated separately in research as well as in management policy. No previous characterization of this sort has been carried out on any penaeid postlarval shrimp, but some limited efforts are available on genetic and biochemical bases in penaeids (Lester 1979). Unfortunately, there have been no practical results. Thorrold et al.
(2002) discussed the problem of quantifying larval retention and connectivity in marine populations with artificial and natural markers. The variation in the integumental pore pattern as a "natural tag", at least in postlarval penaeid populations, may be considers another natural phenotypic marker.

L. vannamei is traditionally important in regional fisheries in its natural range of distribution from Mexico to northern Peru, both in small-scale and commercial fisheries. Since the beginning the 1975, this species has increased in importance and has been the object of aquacultural practices (Andrade 1981), not only in its natural range of distribution but also outside of it. This species for a number of years has been the object of a numerous redistribution inside its natural range of distribution, as the one implied by Alvarez-Silva and Ramirez-Ruiz from Panama to La Paz, B.C.S. Mexico, and also outside its natural range of distribution, in tropical and temperate sites as the mexican coast 
of the Gulf of Mexico: Tamaulipas, Veracruz, Tabasco, Campeche, Yucatan (SEMARNAPMexico, pers. comm.); USA, Caribbean Islands, Tahiti, Hawaii, Taiwan (Lee and Wickins 1992), USA: Texas, Florida, North Carolina (C.R. Mock 1993, Mock pers. comm.).

It may be said that this artificial distribution implies risks of an ecological and pathological nature; moreover the evident aquacultural advantages, there is at least one aquacultural risk in the reduction of survival that will be commented further on. All these man-made redistributions have not been typified on a population basis but it is very important to do so as soon as possible since more of these redistributions are being carried on due to the expansive stage of shrimp aquaculture going on world wide. This consideration is valid not only for L. vannamei but also for any other shrimp species that has been the object of artificial redistribution.

In regards to $L$. vannamei in its natural range of distribution, the importance of the characterization made by Alvarez-Silva and Ramirez Ruiz supports the following considerations. Intraspecific characterization by the integumental pore pattern of postlarval shrimp is needed since it is suspected that there are two groups, probably populations, in the Gulf of California, Mexico; another in the Gulf of Tehuantepec, Mexico, probably extending south to Peru; if not, one or two more in the area from Central America to Peru, in total three to five populations; if not, there is a single gradually changing population along the natural distribution area.

In any case each group or population defined by integumental pore pattern may be adapted to the latitudinal or biogeographic characteristics of the environment that may contribute to explain the differences in domesticity for aquaculture, such as the resistance or sensitivity to viral diseases and other pathological agents, the food conversion indexes and food preferences, the growth indexes, the tolerance to stress of various origins, and other attributes useful in aquaculture, all of which have not yet been defined on a geographic population or group basis. The characterization by integumental pore pattern is an easy low cost but time-consuming procedure; in any event, it is an accessible procedure under the prevalent limited technical or economical circumstances of the area. Nevertheless, it may be interesting to validate results from integumental pore pattern analysis with genetic and biochemical methods as referred by Thorrold et al. (2002).

A risk is also to be considered in view of the unethical practices involving patents of natural genomic resources that sooner or later will touch shrimp resources. It is assumed that in nature there is a genetic interchange between contiguous populations involving the biotic potential of the species, which insures survival as Scheltema proposes for larval dispersal and genetic exchange between geographically separated populations of shallow-water benthic marine gastropods (Scheltema 1971). The problem is that endogamic practices being carried out in commercial laboratories result in a reduced production of shrimp larvae by reproductive females and in the reduction of the survival of larvae and even in the reduction of postlarvae survival in outgrowing facilities. The induced genetic interchange for aquaculture purposes based on populations or groups according to integumental pore pattern could be an interesting resource to improve the productivity both in commercial laboratories producers of postlarvae and in outgrowing facilities.

The characterization made by AlvarezSilva and Ramirez-Ruiz (1999) is also relevant for aquaculture because postlarvae having three dorsal spines are the most abundant on coastal fronts and inlets, and these postlarvae are being collected by thousands of millions of organisms annually to support most of the demand of aquacultural shrimp growers (Cabrera-Jimenez 2001). In other species, postlarvae having four dorsal spines are the more abundant on such 
coastal fronts; this is the case in the Gulf of California, Mexico, regarding L. stylirostris (Stimpson, 1874), Farfantepenaeus californiensis (Holmes, 1900) and F. brevirostris (Kingsley, 1878). It also must be remembered that the number of penaeid shrimp species of world commercial importance is 110 , eight of which are important to the world's aquaculture (Bailey-Brock and Moss 1991); the characterization of postlarvae of these species by the integumental pore pattern could help to rationalize the use of their possible populations to improve results in aquaculture.

\section{ACKNOWLEDGMENTS}

To Samuel Gomez-Aguirre (IB-UNAM), and two anonymous reviewers made constructive criticism of this document. Joseph Doshner (FQ-UNAM) revised the English version.

\section{RESUMEN}

Mediante el análisis del patrón de poros tegumentarios ha sido posible caracterizar a dos grupos intraespecíficos en dos estadios postlarvales del camarón Litopenaeus vannamei. Se estima que se podrán encontrar entre tres y cinco grupos o poblaciones naturales en el área de distribución natural desde México hasta Perú. En ningún peneido se ha tipificado a los grupos o poblaciones naturales, lo cual es muy importante no solamente en relación con las poblaciones en su medio natural, sino también en relación a las redistribuciones hechas por el ser humano. Esto se debe a las implicaciones acuiculturales y a las diferencias en domesticidad, como la resistencia o sensibilidad a enfermedades virales y a otros agentes patógenos, el factor de conversión y las preferencias alimenticias, el índice de crecimiento, la tolerancia al estrés de diversos orígenes y otros atributos útiles en la acuicultura, todos los cuales no están definidos aún sobre la base de grupos o poblaciones geográficas. Esta consideración es válida no solamente para $L$. vannamei sino para cualesquier otra especie de peneido que haya sido objeto de redistribución artificial.
Palabras clave: poslarvas de camarón, acuacultura, población de camarón penaeido, patrón de perforación, Litopenaeus vannamei, artículo de opinión.

\section{REFERENCES}

Alvarez-Silva, C. \& A. Ramírez-Ruíz. 1999. Variación en el patrón de perforación integumental en postlarvas del camarón Penaeus vannamei de Panamá y México. Rev. Biol. Trop. 47: 91-97.

Andrade, G. 1981. Los estanques camaroneros en Ecuador. Rev. Lat. Acui. 7: 22-23.

Bailey-Brock, J.H. \& S.M. Moss. 1991. Penaeid taxonomy, biology and zoogeography. Develop. Aquac. Fish. Sci. 23: 9-28.

Cabrera-Jiménez, J.A. 2001. Contribuciones al conocimiento de la Hidrobiología de las postlarvas de los camarones Farfantepenaeus brevirostris (Kingsley, 1878) y Litopenaeus vannamei (Boone, 1931) (Crustacea, Decapoda, Penaeidae), con énfasis en sus aplicaciones acuiculturales. Tesis de doctorado, Universidad Nacional Autónoma de México. México D.F. 54 p.

Lee, D.O’C. \& J.F. Wickins. 1992. Crustacean farming. Blackwell Scientific, Oxford, England. 392 p.

Lester, L.J. 1979. Population genetics of penaeid shrimp from the Gulf of Mexico. J. Heredity 70: 175-180.

Mauchline, J. 1987. Taxonomic value of pore pattern in the integument of calanoid copepods (Crustacea). J. Zool. Lond. 214: 697-749.

Mock, C.R. 1993. To import or not to import? That is the question! Memorias I Congreso Ecuatoriano de Acuicultura (1992), Quito, Ecuador: 7-16.

Scheltema, R.S. 1971. Larval dispersal as a means of genetic exchange between geographically separated populations of shallow-water benthic marine gastropods. Biol. Bull. 140: 284-322.

Thorrold, S.R., G.P. Jones, M.E. Hellberg, R.S. Burton, S.E. Swearer, J.E. Neigel, S.G. Morgan \& R.R. Warner. 2002. Quantifying larval retention and connectivity in marine populations with artificial and natural markers. Bull. Mar. Sci. 70: 291-308. 
